\title{
Practices to Reduce Milk Carbon Footprint on Grazing Dairy Farms in Southern Uruguay: Case Studies
}

\author{
Carolina Lizarralde ${ }^{1,2}$, Valentin Picasso ${ }^{1}$, C. Alan Rotz ${ }^{3}$, Monica Cadenazzi ${ }^{1}$ \& Laura Astigarraga ${ }^{1}$ \\ ${ }^{1}$ Facultad de Agronomía, Universidad de la República, Montevideo, Uruguay \\ ${ }^{2}$ Instituto Nacional de Investigación Agropecuaria, INIA La Estanzuela, Colonia, Uruguay \\ ${ }^{3}$ USDA / Agricultural Research Service, State College, Pennsylvania, United States \\ Correspondence: Carolina Lizarralde, INIA La Estanzuela, Colonia, Uruguay. Tel: 598-4574-8000. E-mail: \\ clizarralde@inia.org.uy
}

Received: December 21, 2013 Accepted: January 28, 2014 Online Published: February 8, 2014

doi:10.5539/sar.v3n2p1 URL: http://dx.doi.org/10.5539/sar.v3n2p1

\begin{abstract}
Carbon footprint (CF) is an increasingly important indicator of the impact of a product on climate change. This study followed international guidelines to quantify the CF of milk produced on 24 grazing-based dairy farms in southern Uruguay. Cows grazed all year-round and were supplemented with concentrate feeds. Dairy farms varied in annual milk yield per cow $(5672 \pm 1245 \mathrm{~kg}$ fat and protein corrected milk [FPCM]), milk production per ha $(4075 \pm 1360 \mathrm{~kg} \mathrm{FPCM} / \mathrm{ha})$, cow stocking rate $(0.71 \pm 0.12 \mathrm{cows} / \mathrm{ha})$, feed intake $(13.3 \pm 2.2 \mathrm{~kg}$ dry matter $[\mathrm{DM}] /$ cow/day) and percentage of concentrate in the diet $(36 \pm 12 \% \mathrm{DM})$ giving an average $\mathrm{CF}$ of $0.99 \pm$ $0.10 \mathrm{~kg} \mathrm{CO}$ (equivalent [eq] $/ \mathrm{kg} \mathrm{FPCM}$ ) over all farms. Total milk production per ha, milk yield per cow and dry matter intake explained most of the variation in CF. Strategies that provide the highest milk production per ha using high yielding cows and a high portion of lactating cows in the herd were identified as the best management practices for reducing CF. Low forage intake in Uruguay is often a consequence of low yielding pastures and high stocking rates. Overall, this study concluded that a reduction in CF is not achieved through increased concentrate intake unless forage consumption is also unconstrained. Improved pasture and feeding management can be used to reduce the CF of milk produced in Uruguay.
\end{abstract}

Keywords: greenhouse gas emissions, climate change, sustainability, life cycle assessment, multivariate analysis

\section{Introduction}

Livestock are believed to be a significant contributor to climate change, representing $14.5 \%$ of anthropogenic greenhouse gas (GHG) emissions (Gerber et al., 2013). Beef and milk production, are the major contributors and due to their high cattle number the Latin America and the Caribbean regions have been responsible for the highest livestock's emissions, $1.3 \mathrm{Gt} \mathrm{CO}_{2}$ equivalent (eq) (Gerber et al., 2013). In countries with a large livestock industry like Uruguay, agriculture contributes about $80 \%$ of the total GHG emission with most farms using pasture-based livestock production systems (Dirección Nacional de Medio Ambiente [DINAMA], 2010). However, the total GHG emission for Uruguay for the year 2004 represented just $0.05 \%$ of global anthropogenic GHG emissions (DINAMA, 2010). Still GHG emissions have become an important issue for the country due to the large amount of commodities exported, including $74 \%$ of dairy products (Estadísticas Agropecuarias [DIEA], 2013), and the current international concern of consumers for a product's carbon footprint (CF) (Flysjö, Henriksson, Cederberg, Ledgard, \& Englund, 2011; Hermansen \& Kristensen, 2011; Rotz, Montes, \& Chianese, 2010).

A product's CF is the sum of the net GHG emitted throughout the life cycle of the product, within a set of system boundaries, in a specific application, and in relation to a defined amount of a specified product (International Dairy Federation [IDF], 2010). To calculate CF for agricultural products, a life cycle assessment (LCA) is needed where all inputs and outputs of the system are considered up to the farm gate or beyond in the production cycle (Flysjö et al., 2011).

Assessing GHG emissions from dairy production systems as a whole is the best way to measure the effectiveness of mitigation strategies. Several studies have evaluated the influence of management practices on milk CF (Guerci, Bava, Zucali, Sandrucci, \& Penati, 2013; Yan, Humphreys, \& Holden, 2013; Crosson et al., 2011; 
Henriksson, Flysjö, Cederberg, \& Swensson, 2011; Kristensen, Mogensen, Knudsen, \& Hermansen, 2011; Rotz et al., 2010; Beukes, Gregorini, Romera, Levy, \& Waghorn, 2010; Lovett, Shalloo, Dillon, \& O'Mara, 2006; Casey, \& Holden, 2005a, 2005b). For New Zealand grassland systems, Beukes et al. (2010) evaluated the impact of improved cow efficiency (higher genetic merit), improved pasture management (better pasture quality), and maize silage on GHG emissions. Their study concluded that implementation of a combination of strategies could decrease GHG emissions by $27-32 \%$ with the potential of increasing profitability. A study of pastoral based systems in Ireland evaluated two contrasting production systems and determined the effect of six different management scenarios with variations in pasture quality, pasture utilization, nitrogen fertilizer application rate, silage quality, concentrate use and mean calving rate (Lovett et al., 2006). Their findings confirm that simple management changes, if implemented in combination, can be effective in reducing GHG emissions while improving farm profit.

In order to study the impact of management practices at the farm level multivariate analysis is a useful tool. This type of analysis deals with the examination of numerous variables simultaneously in order to study the relationship between them and the CF. To date, a few studies have evaluated the impact of a combination of management practices such as feeding strategies and herd management on milk CF for actual dairy farms using multivariate analysis (Guerci et al., 2013; Yan et al., 2013; Kristensen et al., 2011). In Uruguay, some characteristics of dairy farms and the agriculture sector differ from those of other countries where most of the LCA studies on dairy products have been carried out. Uruguayan dairy farms are characterized by a high diversity of land use and production strategies. Additionally, dairy farms are undergoing a change from grassland-based livestock systems to mixed crop farming systems with increased production levels of raw milk and increased nutrient inputs through purchased feeds and fertilizers (DIEA, 2010). This makes Uruguayan dairy systems a relevant case study of a global trend. Thus, the objectives of this work were to estimate the CF of the milk produced on 24 Uruguayan dairy farms and to evaluate the impact of management practices on this footprint using multivariate analysis.

\section{Method}

\subsection{Uruguayan Milk Production Systems and Data Sources}

In Uruguay, cows normally graze year-round on grass-clover pastures lasting three to four years and annual grass pastures. Varying amounts of conserved forage (maize/sorghum and grass silage) are used to sustain milk production when pasture growth is low. Grass and maize/sorghum silage are usually produced on the farm. During lactation, cows receive concentrates to meet the nutrient requirements of their expected production level. The dairy herd is predominantly Holstein and the average mature cow weight of the herd is $550 \mathrm{~kg}$. Cows calve year-round, but most between March and September to avoid calving during summer. Since the cows graze outdoors year-round, no animal housing is needed and the only building required is a milking parlor. In 2011, a national average production of $4857 \mathrm{~kg}$ milk per cow (3.70\% fat and $3.31 \%$ protein content) was delivered by the dairy industry (DIEA, 2013). The average lactation cycle was about 13 months and replacement heifers were reared on the farm. The average replacement rate of the milking herd was $33 \%$, and heifers typically produced their first calf at 27 months of age (DIEA, 2009).

In this study, we used data collected from 24 actual dairy farms located in southern Uruguay, where most of the dairy farms are located. Farms were not randomly selected, so they were not necessarily a representative sample of the country. Most of the dairy farms analyzed were members of FUCREA (Federación Uruguaya de Consorcios Regionales de Experimentación Agrícola), an Uruguayan farmer's association. The farms selected for the study had a history of good record keeping with the use of professional technical assistance. Therefore, quality data were a criterion for including farms in the study. Another criterion was that heifers were reared on the farm. Information was collected through a semi structured questionnaire and interviews with reference to the fiscal year 2010-2011. The quality of the data was evaluated through expert knowledge. Data collected from dairy farms included productive land area, portion of area occupied by each pasture type, amount and type of concentrate supplied, amount of forage conserved as silage or hay, total milk production, milk yield per cow, milk fat and protein contents, number of cows and replacement stock, cow weight, calving rate, cow replacement rate, age at first calving and mortality rate. Animals sold (culled cows and surplus heifers) were also recorded.

\subsection{Model Used to Quantify Milk Carbon Footprint}

The milk CF for each dairy farm was determined using a software tool called CIPIL (Comisión Inter-CREA de Producción Intensiva de Leche) Dairy System Model (Astigarraga, 2004). This model used an EXCEL spreadsheet format to simulate biological, physical and environmental processes of a dairy farm over a 12 month period. The CIPIL Dairy System Model integrates the animal and forage production activities linked and 
bounded by different constraints: structural (arable land area), agronomic (pasture rotation, expected forage yield and digestibility for each pasture type) and animal (total energy requirement and a limit on ruminal fill). The CIPIL Dairy System Model determines the combination of activities that satisfies all constraints using linear programming. The feed requirements of all animals were calculated using the AFRC system (Agricultural and Feed Research Council [AFRC], 1993), according to their age, live weight, growth rate, milk production per ha and pregnancy status.

The model estimates animal feed intake, performance, and manure production as affected by the indigestibility of the diet consumed by the animals. GHG emissions are estimated based on data from the farm using the tier 2 method of the IPCC (Intergovernmental Panel on Climate Change [IPCC], 2006a; 2006b, 2006c) and following IDF guidelines (IDF, 2010). The contribution of each GHG is integrated using the global warming potential expressed in $\mathrm{kg}$ of equivalent $\mathrm{CO}_{2}\left(\mathrm{~kg} \mathrm{CO}_{2 \mathrm{eq}}\right)$ for a 100 year time horizon. The total is the sum of each of the gases weighted by their respective coefficients of equivalence: $1 \mathrm{~kg} \mathrm{CO}_{2}=1 \mathrm{~kg} \mathrm{CO}_{2} \mathrm{eq}, 1 \mathrm{~kg} \mathrm{CH}_{4}=25 \mathrm{~kg} \mathrm{CO}_{2} \mathrm{eq}$, and $1 \mathrm{~kg} \mathrm{~N} 2 \mathrm{O}=298 \mathrm{~kg} \mathrm{CO}_{2} \mathrm{eq}$ (IPCC, 2007). The outputs of the model were animal production (raw milk, delivered milk, culled cows and heifers sold), milk yield per cow, number of milking cows, calves and heifers, animal feed intake, and purchased feed (concentrate), GHG emissions and CF. To assure that the most important aspects of the farm were properly represented by the model, some variables (total milk production, milk yield per cow, herd composition, cows per ha, total amount of concentrate per cow) were used to verify the ability of the model in representing each farm system.

\subsection{Functional Unit and System Boundaries}

The methodology of the International Dairy Federation (IDF, 2010) was also followed where the functional unit was $1 \mathrm{~kg}$ of fat and protein corrected milk (FPCM). Using FPCM as the basis for farm comparisons assured a fair comparison between farms with different breeds or feed regimes producing differing levels of milk solids. Dairy production may be defined as multifunctional, where meat is also a saleable product. Several methodologies, can be used to allocate emissions across these co-products, but the methodology chosen affects estimations of GHG intensity on dairy products (Mc Geough et al., 2012; Flysjö et al., 2011; Cederberg \& Stading, 2003). In our study, allocation between milk and meat was done using the biological method as recommended by IDF (2010), based on the feed energy required to produce the amount of milk and meat leaving the farm.

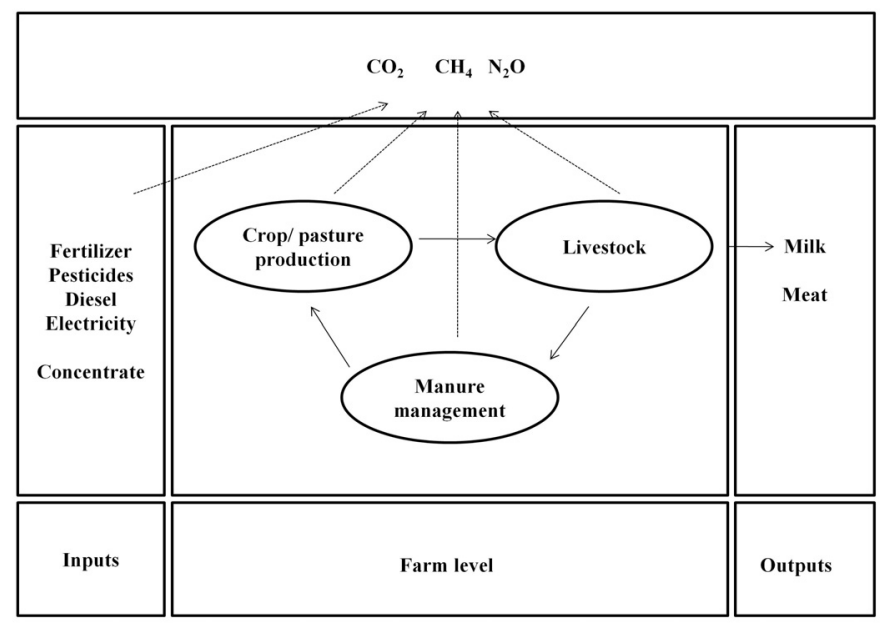

Figure 1. Emission sources contributing to the carbon footprint of dairy production systems

System boundaries were defined as "cradle to farm-gate". All important emissions of $\mathrm{CH}_{4}, \mathrm{~N}_{2} \mathrm{O}$ and $\mathrm{CO}_{2}$, associated with the production of resource inputs to the dairy farm, were accounted along with the direct emissions from the farm (Figure 1). Resource inputs included were the production of fuel, electricity, synthetic fertilizer, pesticides and seed. For practicality, IDF guidelines (2010) accept that any material or energy flow that contributes less than one percent of total emissions can be excluded. On this basis, emissions associated with the construction of agricultural buildings, machinery and plastic used on the farm were not included. Biogenic $\mathrm{CO}_{2}$ emissions generated from feed, animal, and manure sources were also ignored assuming that they were offset by 
carbon fixation in growing feed crops.

In the last two decades, the land area used in dairy production in Uruguay has decreased (DIEA, 2012) and deforestation is not a usual practice. Therefore, we assumed there was no change in land use associated with milk production.

\subsection{Greenhouse Gas Associated With the Dairy System}

\subsubsection{Methane}

Methane is produced by ruminants mainly as a by-product of enteric fermentation. For estimating methane emissions, average daily feed intake expressed as gross energy intake was calculated from the diet for the dairy cows as determined by the CIPIL Dairy System Model. The methane conversion factor ( $\mathrm{Ym}=6.5 \%$ of gross energy intake) was taken from IPCC (2006a), which was similar to experimental results reported by Dini et al. (2012) for grazing dairy cows in Uruguay.

The decomposition of manure (dung and urine) under anaerobic conditions during storage and treatment also produces $\mathrm{CH}_{4}$. Estimated excretions were obtained using the dry matter intake and diet digestibility determined by the model. As cows graze year-round, we assumed that $90 \%$ of the urine and dung were deposited on pasture and the $\mathrm{CH}_{4}$ emissions from these were considered negligible. The other $10 \%$ was assumed to be excreted at the milking shed being managed using an uncovered anaerobic lagoon system. This assumption was used because differences in management of the small amount of manure obtained from the milking shed would have little impact on the overall CF. Emissions were determined using a methane conversion factor of $76 \%$ and a maximum $\mathrm{CH}_{4}$ production capacity for dairy manure of $0.24 \mathrm{~m}^{3}$ of $\mathrm{CH}_{4} / \mathrm{kg}$ of daily volatile solids excretion (IPCC, 2006a).

\subsubsection{Nitrous Oxide}

Nitrous oxide emissions from soil increase through enhanced nitrification and denitrification rates as available soil $\mathrm{N}$ increases (IPCC, 2006b). Direct emissions of $\mathrm{N}_{2} \mathrm{O}$ from the soil and stored manure were also estimated following IPCC guidelines (2006b) and their corresponding default emission factors (EF). For synthetic $\mathrm{N}$ fertilizer, the EF was $0.01 \mathrm{~kg} \mathrm{~N}_{2} \mathrm{O}-\mathrm{N}$ per $\mathrm{kg} \mathrm{N}$ applied. Since $90 \%$ of the excreta were dropped directly on pasture, that portion of manure $\mathrm{N}$ was applied to grassland. The $\mathrm{N}$ in excreta was calculated as the total $\mathrm{N}$ in feed intake minus the $\mathrm{N}$ in milk and that retained in animals (calf and heifer growth). The $\mathrm{EF}$ used was $0.02 \mathrm{~kg}$ $\mathrm{N}_{2} \mathrm{O}-\mathrm{N} / \mathrm{kg} \mathrm{N}$ excreted. Manure in the lagoon system was considered to have negligible $\mathrm{N}_{2} \mathrm{O}$ emission prior to land application (IPCC, 2006b).

Volatilization of $\mathrm{NH}_{3}$ and leaching of $\mathrm{NO}_{3}$ create indirect emissions of $\mathrm{N}_{2} \mathrm{O}$. For $\mathrm{NH}_{3}$ volatilization's effect on $\mathrm{N}_{2} \mathrm{O}$ emission through atmospheric deposition of $\mathrm{N}$ on soils and water surfaces, an EF of $0.010 \mathrm{~kg} \mathrm{~N} \mathrm{~N}_{2} \mathrm{O}-\mathrm{N} / \mathrm{kg}$ of emitted $\mathrm{N}$ was used (IPCC, 2006b). The fraction of $\mathrm{N}$ that volatilizes as $\mathrm{NH}_{3}$ and $\mathrm{NOx}$ under different conditions was $0.10 \mathrm{~kg}$ and $0.20 / \mathrm{kg}$ of $\mathrm{N}$ from synthetic fertilizer applied or excreted respectively. The leaching factor used was $30 \%$ of applied $\mathrm{N}$ and depositions, while the $\mathrm{EF}$ for $\mathrm{N}_{2} \mathrm{O}$ emissions from leached and runoff $\mathrm{N}$ was 0.0075 $\mathrm{kg} \mathrm{N}{ }_{2} \mathrm{O}-\mathrm{N} / \mathrm{kg}$ of $\mathrm{N}$ loss (IPCC, 2006b).

\subsubsection{Carbon Dioxide}

In Uruguay, electricity is mainly used on farms for milking and milk cooling. For all farms, $\mathrm{CO}_{2}$ emission during the production of electricity was estimated at $0.463 \mathrm{~kg} \mathrm{CO}_{2}$ eq / $\mathrm{kWh}$ (Cabal, Fontana, Garcia Pini, \& Kramer, 2009). During the operation of tractors and other engine-powered equipment, $\mathrm{C}$ in diesel is transformed to $\mathrm{CO}_{2}$ and released in engine exhaust (Rotz et al., 2010). The quantity of diesel fuel used per ha or per hour for pasture maintenance and feed production operations was taken from CUSA (Cámara Uruguaya de Servicios Agropecuarios [CUSA], 2011). The EF for diesel fuel was taken from IPCC (2006c) and adjusted for emissions from transportation, giving a value of $2.98 \mathrm{~kg} \mathrm{CO}_{2}$ eq / $\mathrm{kg}$ of diesel fuel consumed. Methodology described by Spielmann, Dones and Bauer (2007) was used to calculate EF of for the extraction of raw materials, manufacture, and transport of fertilizers and pesticides. Means of transportation and amounts imported in the last 5 years were obtained from the Asociación Latinoamericana de Integración [ALADI] (2011). The synthetic nitrogen fertilizer used in Uruguay is mainly urea; the EF was $0.793 \mathrm{~kg} \mathrm{CO}_{2} \mathrm{eq} / \mathrm{kg}$ of urea used. For the dairy farms studied, a typical nitrogen fertilizer rate of $40 \mathrm{~kg} \mathrm{~N} /$ ha was used in accordance with Díaz-Rossello and Durán (2011). The off-farm emissions of purchased feed were also taken into account.

\subsection{Statistical Analysis}

To identify the variables that best explained the differences in CF among the 24 farms, correlation analyses between $\mathrm{CF}$ and ten possible explanatory variables were determined: milk yield per cow, milk production per ha, cow stocking rate, herd efficiency (milking cows over total animals), concentrate per cow, proportion of 
concentrate fed in diets, forage consumption per cow, dry matter intake per cow, $\mathrm{N}$ excreted per cow, $\mathrm{N}$ excreted per hectare, and CF. For the variables most highly correlated to CF, regression analysis was conducted.

Some management variables were strongly correlated with one another, which made interpretation of relationships between individual variables and CF difficult. We used principal component analysis (PCA) to reduce the number of variables. PCA can be conducted as long as there are fewer variables than data, but higher ratios of data to variables are recommended. We therefore removed agricultural variables that were collinear (e.g. concentrate in the diet and the concentrate fed per cow were highly correlated). We retained the following eight variables: milk yield (kg FPCM/cow/year), milk production ( $\mathrm{kg} \mathrm{FPCM} / \mathrm{ha} /$ year), stocking rate (cows/ha), herd efficiency (milking cows/total stock), concentrate use per cow (kg dry matter [DM]/cow/day), dry matter intake per cow (kg DM/cow/day), $\mathrm{N}$ excreted per hectare ( $\mathrm{kg} \mathrm{N} / \mathrm{ha} /$ year), and $\mathrm{CF}(\mathrm{kg} \mathrm{CO} 2$ eq/kg FPCM). The PCA allowed the transformation of a set of correlated explanatory variables to new variables, the so-called principal components (PCs), which were all linear combinations of the original correlated variables.

A cluster analysis was used to study the distribution of farms when placed into homogenous groups. The classification technique selected was the ward hierarchic method. The same variables used in the PCA were retained, and as the data have metrical properties, euclidean distance was used. All statistical analyses were performed using the software InfoStat (2012).

\section{Results}

\subsection{Characteristics of the Dairy Farms}

Table 1. Mean, coefficient of variance (CV), maximum and minimum values for farm size, milk production, herd and feeding characteristics, $\mathrm{N}$ excreted, and carbon footprint for 24 grazing dairy farms in Uruguay

\begin{tabular}{|c|c|c|c|c|c|}
\hline Parameter & Units & Mean & $\mathrm{CV}$ & Maximum & Minimum \\
\hline \multicolumn{6}{|l|}{ PRODUCTION } \\
\hline Farm size & ha & 445 & $62 \%$ & 1044 & 55 \\
\hline Annual milk production & t FPCM per year & 1821 & $71 \%$ & 5334 & 186 \\
\hline Milk production & kg FPCM per ha & 4075 & $33 \%$ & 7362 & 1883 \\
\hline Milk yield & kg FPCM per cow & 5672 & $22 \%$ & 7772 & 3184 \\
\hline Milk fat content & $\%$ & 3.72 & $5 \%$ & 4.32 & 3.42 \\
\hline Milk protein content & $\%$ & 3.35 & $4 \%$ & 3.77 & 3.19 \\
\hline \multicolumn{6}{|l|}{ HERD } \\
\hline Stocking rate & cows per ha & 0.71 & $18 \%$ & 1.05 & 0.48 \\
\hline Herd efficiency & $\begin{array}{l}\text { milking cows over total } \\
\text { stock }\end{array}$ & 0.42 & $10 \%$ & 0.48 & 0.28 \\
\hline Calving rate & $\%$ & 80 & $11 \%$ & 96 & 66 \\
\hline Replacement rate & $\%$ & 28 & $10 \%$ & 35 & 25 \\
\hline Age at first calving & months & 27.8 & $11 \%$ & 35.4 & 24.0 \\
\hline \multicolumn{6}{|l|}{ FEEDING } \\
\hline Pasture yield & kg DM per ha & 6421 & $17 \%$ & 9037 & 4586 \\
\hline Concentrate fed & kg DM per cow per day & 4.9 & $40 \%$ & 7.6 & 1.9 \\
\hline Concentrate in diet & $\%$ & 36 & $33 \%$ & 56 & 17 \\
\hline Forage fed & kg DM per cow per day & 8.4 & $20 \%$ & 12.0 & 5.4 \\
\hline Total feed intake & kg DM per cow per day & 13.3 & $17 \%$ & 17.2 & 7.8 \\
\hline \multicolumn{6}{|l|}{ N EXCRETED } \\
\hline $\mathrm{N}$ excreted/ ha & kg N per ha per year & 84 & $20 \%$ & 128 & 63 \\
\hline $\mathrm{N}$ excreted / cow & kg N per cow per year & 119 & $10 \%$ & 145 & 99 \\
\hline CARBON FOOTPRINT & $\mathrm{kg} \mathrm{CO} 2$ eq. per FPCM & 0.99 & $10 \%$ & 1.24 & 0.87 \\
\hline
\end{tabular}


The mean and variation of the main variables analyzed for the 24 dairy farms are shown in Table 1 . The largest variations among the 24 dairy farms analyzed were farm size and annual milk production. There was some variation in milk production per ha $(4075 \pm 1360 \mathrm{~kg} \mathrm{FPCM} / \mathrm{ha}, \mathrm{CV}=33 \%)$, milk yield per cow $(5672 \pm 1254 \mathrm{~kg}$ $\mathrm{FPCM} / \mathrm{cow}, \mathrm{CV}=22 \%)$ and stocking rate $(0.71 \pm 0.12 \mathrm{cows} / \mathrm{ha}, \mathrm{CV}=18 \%)$. Herd efficiency (number of milking cows divided by the number of animals in the whole herd) was $0.42 \pm 0.04(\mathrm{CV}=10 \%)$, with a calving rate of $80 \pm 8.6 \%$, an age at fist calving of $28 \pm 3.0$ months, and a replacement rate of $28 \pm 3 \%$. The variation in concentrate feed intake was large $(\mathrm{CV}=40 \%)$ with an average of $4.9 \pm 2.0 \mathrm{~kg} / \mathrm{cow} / \mathrm{day}$. This represented $36 \pm$ $12 \%$ of the daily dry matter intake per cow. Finally, the calculated cradle-to-farm-gate CF for the 24 dairy farms was $0.99 \pm 0.10 \mathrm{~kg} \mathrm{CO} 2 \mathrm{eq} / \mathrm{kg}$ FPCM $(\mathrm{CV}=10 \%)$.

\subsection{Principal Variables Related to Carbon Footprint}

To identify variables that best explained the variation in CF among the 24 dairy farms, ten farm variables were selected and a correlation analysis was done. The correlation matrix revealed the correlation of CF with farm variables related to milk production, herd efficiency, and diet characteristics (Table 2). The highest correlations were with milk yield per cow $(\mathrm{r}=-0.81, \mathrm{P}<0.05)$, milk production per ha $(\mathrm{r}=-0.78, \mathrm{P}<0.05)$, dry matter intake per cow $(\mathrm{r}=-0.69, \mathrm{P}<0.05)$ and concentrate fed per cow $(\mathrm{r}=-0.71, \mathrm{P}<0.05)$.

Table 2. Matrix of simple correlations (below the diagonal) and probability of significance ${ }^{1}$ (above the diagonal) between the main variables of the 24 farms

\begin{tabular}{llllllllllll}
\hline & MPA & SR & MYC & HE & CC & CD & FC & FI & NEC & NEH & CF \\
\hline MPA & & $<0.05$ & $<0.05$ & $<0.05$ & $<0.05$ & $<0.05$ & NS & $<0.05$ & NS & $<0.05$ & $<0.05$ \\
SR & 0.82 & & $<0.05$ & $<0.05$ & $<0.05$ & NS & NS & $<0.05$ & NS & $<0.05$ & $<0.05$ \\
MYC & 0.87 & 0.44 & & $<0.05$ & $<0.05$ & $<0.05$ & $<0.1$ & $<0.05$ & $<0.05$ & $<0.05$ & $<0.05$ \\
HE & 0.71 & 0.45 & 0.77 & & $<0.05$ & $<0.05$ & NS & $<0.05$ & NS & $<0.05$ & $<0.05$ \\
CC & 0.72 & 0.42 & 0.79 & 0.65 & & $<0.05$ & NS & $<0.05$ & NS & $<0.05$ & $<0.05$ \\
CD & 0.52 & 0.32 & 0.54 & 0.44 & 0.94 & & $<0.05$ & $<0.05$ & NS & NS & $<0.05$ \\
FC & 0.25 & 0.04 & 0.37 & 0.34 & -0.25 & 0.56 & & $<0.05$ & $<0.05$ & NS & NS \\
FI & 0.82 & 0.40 & 0.97 & 0.82 & 0.69 & 0.41 & 0.52 & & $<0.05$ & $<0.05$ & $<0.05$ \\
NEC & 0.21 & -0.09 & 0.40 & 0.22 & 0.02 & -0.23 & 0.65 & 0.51 & & $<0.05$ & NS \\
NEH & 0.86 & 0.85 & 0.61 & 0.51 & 0.43 & 0.22 & 0.33 & 0.62 & 0.42 & & $<0.05$ \\
\hline CF & -0.78 & -0.52 & -0.81 & -0.55 & -0.71 & -0.56 & -0.10 & -0.69 & -0.07 & -0.51 & \\
\hline
\end{tabular}

MPA: milk production per land area; SR: stocking rate; MYC: milk yield per cow; HE: herd efficiency; CC: concentrate per cow; CD: concentrate in diet; FC: forage per cow; FI: feed intake; NEC: nitrogen excreted per cow; NEH: nitrogen excreted per ha; CF: carbon footprint.

${ }^{1}$ Significant $(\mathrm{P}<0.05)$, trend $(\mathrm{P}<0.1)$, and not significant $(\mathrm{NS})$.

For the two variables with the highest correlation, regression analyses of their relationship with $\mathrm{CF}$ were conducted. Significant and decreasing relationships were found for milk yield and milk production effects on $\mathrm{CF}$ (Figures 2 and 3). Milk CF as a function of milk production per unit of land area (MPA) was represented by $\mathrm{CF}$ $=6.024 \mathrm{MPA}^{-0.219}\left(\mathrm{R}^{2}=0.69, \mathrm{P}<0.001\right)$, and the milk CF as a function of milk yield per cow $(\mathrm{MYC})$ was $\mathrm{CF}=$ 16.367 $\mathrm{MYC}^{-0.326}\left(\mathrm{R}^{2}=0.68, \mathrm{P}<0.001\right)$. In both cases, the model was a declining exponential function, which means that $\mathrm{CF}$ declines at a decreasing rate as the milk yield (per hectare or per cow) increases. 


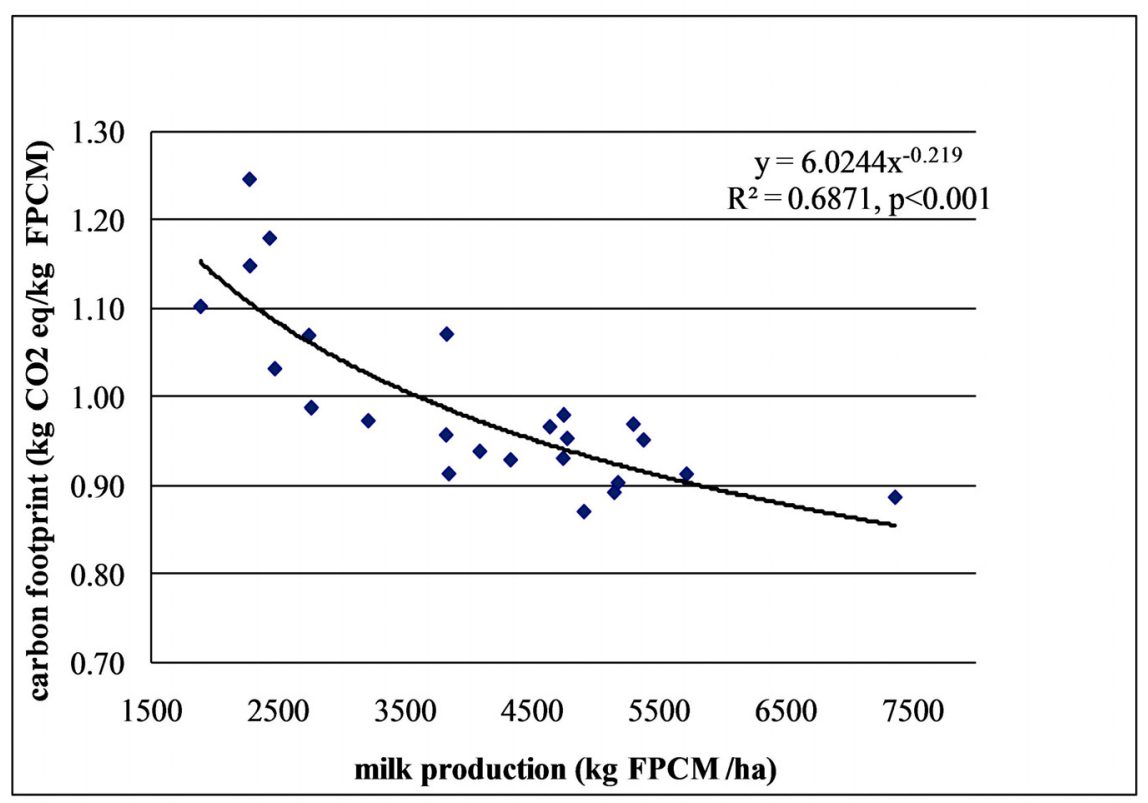

Figure 2. Relationship between carbon footprint and milk production per ha

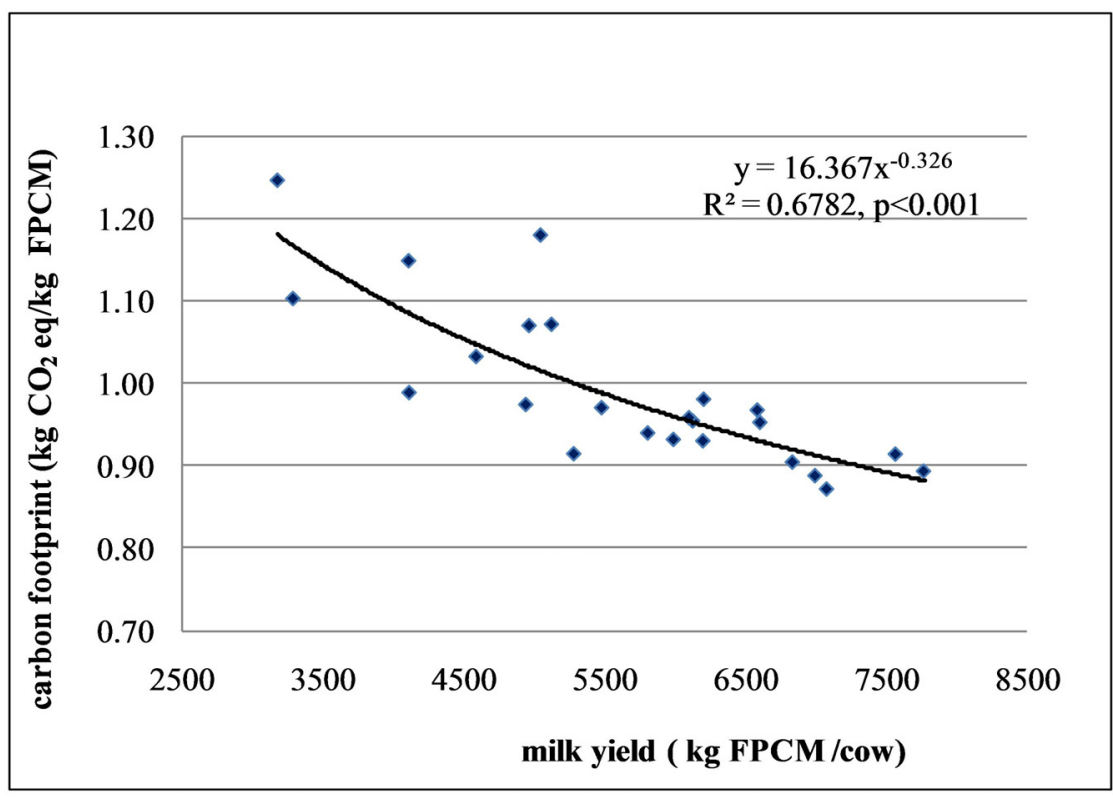

Figure 3. Relationship between carbon footprint and milk yield per cow

\subsection{Multivariate Analysis}

The PCA showed that two PCs with eigenvalues $>0.35$ explained $86 \%$ of the total variance among the dairy farms (Figure 4). 


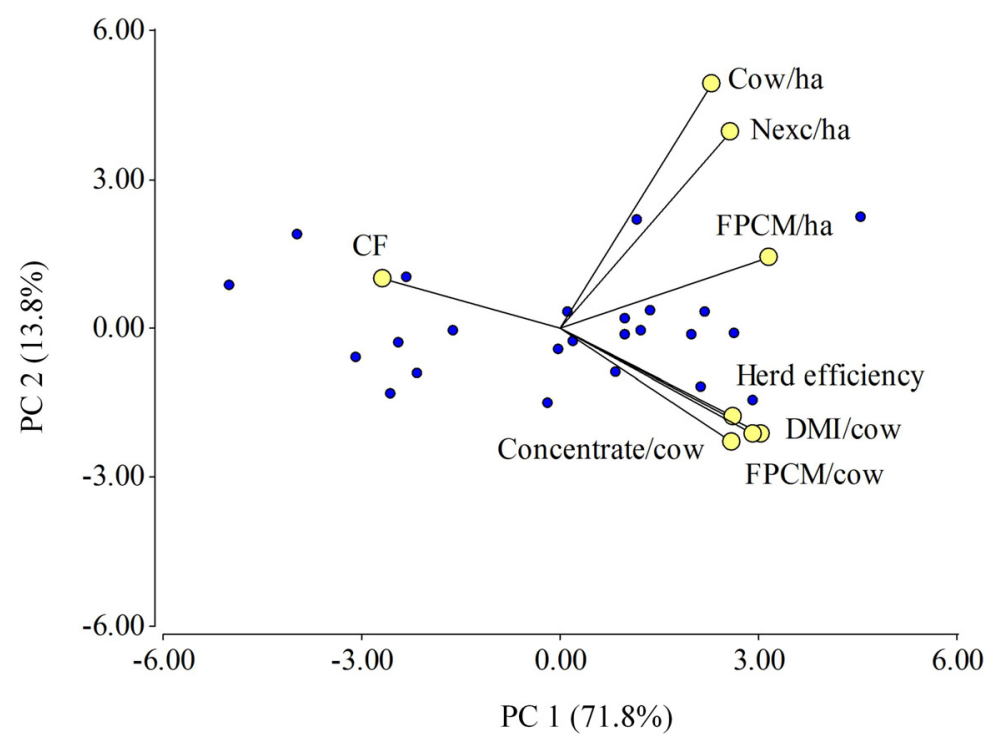

Figure 4. Projection of technical variables of dairy farms on axes 1 and 2 defined by the principal component analysis

As two eigenvalues of the correlation matrix describing farm variables were larger than the preselected minimum of 1 (Kaiser criterion; Massart, Vandeginste, Deming, Michotte, \& Kaufman, 1988) and accounted for 86\% of the total variance in the data set, these two principle components were retained. The first PC explained $72 \%$ of the variation and it was composed of variables related to milk yield (per ha and per cow) feed and herd management practices. The second component explained $14 \%$ of the variation through variables expressed per hectare (stocking rate and $\mathrm{N}$ excreted per ha).

Table 3 shows the eigenvectors (weights or loadings) for the standardized descriptive farm variables corresponding to each PC. The first PC is mainly explained by herd and feed variables all of them with positive loadings, except $\mathrm{CF}$ which has a negative effect. Milk production and milk yield had the greatest effects. Therefore, increased milk production, milk yield, dry matter intake per cow and herd efficiency all lead to a reduced on milk CF. The second PC describes variables expressed per ha, such is the case of stocking rate and $\mathrm{N}$ excreted which have positive loadings. There was little effect of these variables on the milk CF.

Table 3. Eigenvectors corresponding to the two principal components retained for the 24 dairy farms

\begin{tabular}{llll}
\hline \multirow{2}{*}{ Descriptive farm variables } & Units & \multicolumn{2}{l}{ Eigenvectors } \\
\cline { 3 - 4 } & & PC1 & PC2 \\
\hline Milk production & $\mathrm{kg} \mathrm{FPCM} / \mathrm{ha}$ & 0.41 & 0.18 \\
Stocking rate & $\mathrm{cows} / \mathrm{ha}$ & 0.30 & 0.63 \\
Herd efficiency & $\mathrm{milk} \mathrm{cows} /$ total animals & 0.34 & -0.23 \\
Concentrate & $\mathrm{kg} \mathrm{DM} /$ cow/day & 0.33 & -0.30 \\
Dry matter intake & $\mathrm{kg} \mathrm{DM} /$ cow/day & 0.38 & -0.27 \\
$\mathrm{~N}$ excreted & $\mathrm{kg} \mathrm{N} / \mathrm{ha}$ & 0.33 & 0.51 \\
Milk yield & $\mathrm{kg} \mathrm{FPCM} / \mathrm{cow}$ & 0.39 & -0.27 \\
Milk CF & $\mathrm{kg} \mathrm{CO}$ eq/kg FPCM & -0.34 & 0.13 \\
\hline
\end{tabular}

Subsequently, a cluster analysis based on values of these two PCs resulted in three farm clusters, each containing data from 7 to 9 dairy farms. Table 4 shows average data for the descriptive farm variables of each cluster. 
Table 4. Average data for the descriptive farm variables corresponding to each cluster of similar farms

\begin{tabular}{lllll}
\hline \multirow{2}{*}{$\begin{array}{l}\text { Descriptive } \\
\text { variables }\end{array}$} & farm & \multicolumn{3}{l}{ Farm cluster } \\
\cline { 3 - 5 } & & 1 & 2 & 3 \\
\hline Farms & Number & 8 & 7 & 9 \\
Milk production & $\mathrm{kg} \mathrm{FPCM} / \mathrm{ha}$ & 2502 & 4198 & 5377 \\
Stocking rate & $\mathrm{cow} / \mathrm{ha}$ & 0.60 & 0.72 & 0.80 \\
Milk yield & $\mathrm{kg} \mathrm{FPCM} / \mathrm{cow}$ & 4285 & 5821 & 6788 \\
Herd efficiency & $\mathrm{milking} \mathrm{cows} /$ total cattle & 0.38 & 0.44 & 0.45 \\
Concentrate fed & $\mathrm{kg} \mathrm{DM} /$ cow/day & 2.6 & 6.3 & 5.9 \\
Dry matter intake & $\mathrm{kg} \mathrm{DM} / \mathrm{cow} / \mathrm{day}$ & 11.0 & 13.3 & 15.2 \\
Nitrogen excreted & $\mathrm{kg} \mathrm{N} / \mathrm{ha}$ & 70 & 79 & 101 \\
Nitrogen excreted & $\mathrm{g} \mathrm{N} / \mathrm{kg} \mathrm{FPCM}$ & 28.0 & 18.8 & 18.8 \\
Milk carbon footprint & $\mathrm{kg} \mathrm{CO}$ eq/kg FPCM & 1.09 & 0.96 & 0.92 \\
\hline
\end{tabular}

Cluster 1 includes 8 farms that showed low herd milk production due to a low milk yield per cow as well as a low stocking rate. Additionally, herd efficiency (proportion of milking cows in the herd) was low. The low milk yield per cow was due to a low dry matter intake per cow with a low proportion of concentrate in the diet (23\%). As a result, this group showed the highest milk CF.

On the other side, Cluster 3 contained 9 farms characterized by high milk production due to a high milk yield per cow and high stocking rate. Herd efficiency was high as well. These farms used feed management practices with a higher forage intake per cow and a high proportion of concentrate in diets (39\%). This group resulted in the lowest milk CF. However, the $\mathrm{N}$ excreted per hectare was higher than that of the other clusters though, which could lead to other environmental concerns from leaching and runoff of $\mathrm{N}$. Cluster 2 was made up of 7 farms with intermediate production values.

The contribution of the different GHG sources associated with the milk CF for each cluster is presented in Figure 5. For the three clusters, enteric fermentation was the largest contributor to milk $\mathrm{CF}$, providing around half the total GHG emissions (57\% for cluster 1 and $50 \%$ for clusters 2 and 3). Direct emissions of nitrous oxide from excreta deposited during grazing and indirect emissions of nitrous oxide from volatilized and leached nitrogen were higher for cluster 1 (Table 4).

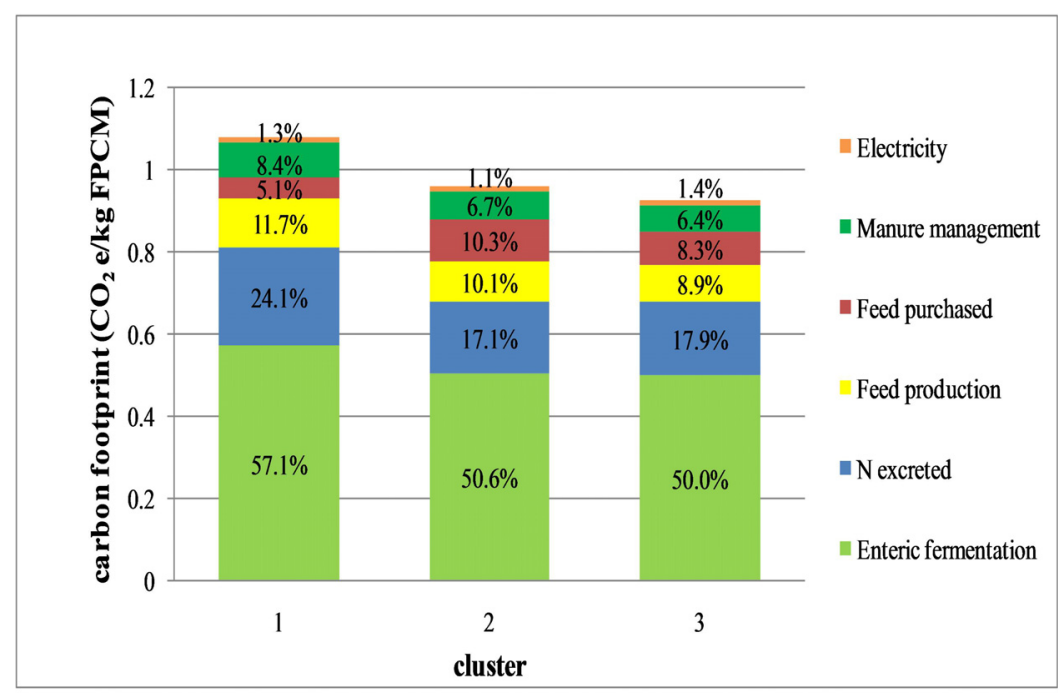

Figure 5. Farm gate carbon footprint per $\mathrm{kg}$ of fat and protein corrected milk (FPCM) for each cluster of farms broken down by source of emission (\%) 
Production of feed (including fertilizer and diesel fuel production, energy for feed processing, and emissions from the field) generated a greater portion of total GHG emissions per $\mathrm{kg}$ FPCM as milk production declined, i.e. these GHG emissions provided a greater portion of the total on a per unit of milk produced basis for farms in cluster 1. On the other side, GHG emissions for purchased feed were higher for clusters 2 and 3. Emissions from manure management accounted for around $7 \%$ of the total. Although the EF was 10 times greater from a lagoon system than from excreta deposited in pasture, the weight of this activity on milk CF was lower as most of the excreta were on the pasture. The energy consumption in the parlor (electricity) made a relatively small contribution to the overall $\mathrm{CF}$.

\section{Discussion}

Uruguay is a non-Annex I country in the Kyoto Protocol with no legally binding targets. Still GHG emissions have become a relevant issue for the government and scientists of this country. Both are members of the Global Research Alliance on agricultural GHG, which focuses on research and practices that increase food production without increasing emissions.

This study provides the first assessment of milk CF for Uruguayan dairy production systems. These data represent those regions (soil type and production systems) in the country where most of the milk production is located. Although the farms were not selected at random and therefore may not be representative of all dairy farms in the country, they provided the ability to study variations over a large number of farms. As expected and because of the use of professional technical assiantance the dairy farms analyzed produced $70 \%$ more milk than the average estimated for Uruguayan dairy farms (DIEA, 2009). Also milk yield per cow, expressed in kg FPCM, and stocking rate were approximately $22 \%$ and $39 \%$ greater than the Uruguayan average (DIEA, 2009).

Average milk $\mathrm{CF}$ for the 24 farms was $0.99 \mathrm{~kg} \mathrm{CO} 2 \mathrm{eq} / \mathrm{kg}$ FPCM. The variation in production data found among the studied dairy farms suggests that the CF of Uruguayan milk production varies by at least $\pm 10 \%$. The actual variation is probably greater, since the production data used in our study were obtained from dairy farms with greater milk yield per cow than the average milk produced in Uruguay (Table 1).

Soil carbon sequestration is another consideration that can further contribute to mitigation (Gerber et al., 2013; IDF, 2010; Rotz et al., 2009). In the last ten years, Uruguayan dairy farms have changed their management practices towards intensification and they have moved from the use of tillage to no tillage systems for crop establishment. Results from Díaz-Rossello and Durán (2011) reported an annual sequestration of $3483 \mathrm{~kg} \mathrm{CO}_{2}$ eq per ha on actual dairy farms due to these management changes. Including these changes in soil organic matter, reduces our average $\mathrm{CF}$ from 0.99 to $0.14 \mathrm{~kg} \mathrm{CO}_{2}$ eq/FPCM during the transition period where the soil $\mathrm{C}$ level increases to a new balance. This result is similar to that reported by Rotz et al. (2009) for Pennsylvania dairy farms.

The variation in milk CF presented here is in the same range of those reported in earlier LCA studies for grazing dairy systems (Belflower et al., 2012; O'Brien et al., 2012; Flysjö et al., 2011; Castanheira, Dias, Arroja, \& Amaro, 2010; Basset-Mens, Ledgard, \& Boyes, 2009; Lovett et al., 2006; Cassey \& Holden, 2005b; Hospido, Moreira, \& Feijoo, 2003). However, as studies differ in methodology, comparison of results from different studies must be done with caution. The methodology used to estimate GHG emissions including methods for quantifying production, system boundary setting, the functional unit, and co-product allocation significantly affect the calculated CF. Since 2010, IDF has provided guidelines to help standardize the calculation of milk CF. Some papers published after this date have used this methodology, such as Flysjö et al. (2011). To compare our results to their values, we can use their assumed EF and no allocation. The average milk CF for the 24 farms studied is then $1.04 \mathrm{~kg} \mathrm{CO}$ eq/FPCM and the $\mathrm{CF}$ of the clusters 1,2 and 3 are $1.20,1.00$ and $0.94 \mathrm{~kg} \mathrm{CO}$ eq/FPCM respectively. The values reported by Flysjö et al. (2011) were $1.00 \mathrm{~kg} \mathrm{CO}_{2}$ eq/FPCM for New Zealand and $1.16 \mathrm{~kg} \mathrm{CO}_{2}$ eq/FPCM for Sweden. This comparison indicates that milk produced in Uruguay creates similar GHG emissions as milk produced in other developed countries.

\subsection{Effect of Milk Yield}

Many studies have shown the impact of milk yield on CF (Belflower et al., 2013; Gerber et al., 2013; Yan et al., 2013; Henriksson et al., 2011; Iribarren, Hospido, Moreira, \& Feijoo, 2011; Kristensen et al., 2011; Rotz et al., 2010; Lovett et al., 2006; Casey \& Holden, 2005a) and this has often been described as a linear relationship. For example, Casey and Holden (2005b) found a decreasing linear relationship between MYC and CF (CF $=-0.0002$ $\left.\mathrm{MYC}+1.93, \mathrm{R}^{2}=0.87\right)$. However, their data can also support a nonlinear relationship similar to ours $(\mathrm{CF}=204$ $\mathrm{MYC}^{-0.61}, \mathrm{R}^{2}=0.88$ ) with a slightly greater correlation between $\mathrm{CF}$ and milk yield per cow. A linear relationship suggests that at some milk yield CF will be zero, which is not biologically possible. In the same way, the CF data reported by Hagemann, Hemme, Ndambi, Alqaisi and Sultana (2011) for many different counties can also be 
represented by a decaying exponential relationship with milk yield $\left(\mathrm{CF}=122.7 \mathrm{MYC}^{-0.54}, \mathrm{R}^{2}=0.92\right)$.

This exponential decline is a result of fewer cows being maintained to produce a given amount of milk. Methane emissions are influenced by the maintenance of animals as well as the production of milk, so maintaining more animals per unit of milk produced increases the CF, i.e. the portion of feed energy used for animal maintenance decreases as milk yield per cow increases. The importance of cow productivity is highlighted in Figure 5. Because enteric emissions contribute the largest portion of total emissions, the key drivers of production, such as genetic merit for milk production and feed management, are important targets for emission abatement.

\subsection{Effect of Milk Production}

Of all milk CF studies, only the pastoral based systems (Guerci et al., 2013; Yan et al., 2013; Flysjö et al., 2011; Hagemann et al., 2011; Iribarren et al., 2011; Beukes et al., 2010; Rotz et al., 2010; Basset-Mens et al., 2009; Rotz et al., 2009; Lovett, Shalloo, Dillon, \& O`Mara, 2006, 2008; Casey \& Holden, 2005a, 2005b; Hospido et al., 2003) have reported milk production per unit of land area ( $\mathrm{kg} \mathrm{FPCM} / \mathrm{ha})$. Few studies have evaluated the relationship between milk production per unit land area (MPA, $\mathrm{kg} / \mathrm{ha}$ ) and CF. Our study identifies a strong relationship between these two variables. Improving milk production decreases $\mathrm{CF}$ if this production is associated with high yielding cows with greater feed efficiency (Figure 2).

Data from Casey and Holden (2005b) showed a similar trend in relating milk production per unit of land area to $\mathrm{CF}\left[\mathrm{CF}\left(\mathrm{kg} \mathrm{CO}_{2} \mathrm{eq} / \mathrm{kg} \mathrm{FPCM}\right)=70.21 \mathrm{MPA}^{-0.45}, \mathrm{R}^{2}=0.69\right]$. Also for Ireland, the results reported by Lovett et al. (2006) can be plotted as a decaying exponential relationship with milk production per hectare [CF $\left(\mathrm{kg} \mathrm{CO}_{2}\right.$ eq $/ \mathrm{kg}$ FPCM $\left.)=104.25 \mathrm{MPA}^{-0.48}, \mathrm{R}^{2}=0.91\right]$. Finally, the same form of relationship can be used to describe the results of Hagemann et al. (2011) for milk yield per land area among different regions of the world $\left[\mathrm{CF}\left(\mathrm{kg} \mathrm{CO} \mathrm{CO}_{2}\right.\right.$ eq/ $\mathrm{kg}$ FPCM $\left.=36.85 \mathrm{MPA}^{-0.365}, \mathrm{R}^{2}=0.77\right]$.

\subsection{Effect of Management Practices}

Results of the PCA showed that two axes accounted for $86 \%$ of the total variation among farms, and those axes were mainly explained by feeding practices and herd management. The primary axis, which represented $71.8 \%$ of the total variation, was interpreted as an axis differentiating farms with respect to milk yield per cow and concentrate feeding level per cow (Table 3). Hence, it was considered as an axis which contributed to a better analysis of cattle feeding strategies with variables that showed a high (negative) correlation with CF. The second axis explained $13.8 \%$ of the total variation and was mainly related to stocking rate and nitrogen excreted/ha (Table 3). Thus, this axis emphasized differences among farms for variables related to land management (variables per ha) but with a lower correlation to CF (Table 2). The results suggest that improvements in feed efficiency and herd performance will decrease the CF. Likewise, Gerber et al. (2013) identified improvements in feed and feeding practices, and better health and herd management practices as important mitigiation options for reducing $\mathrm{CF}$.

In the cluster analysis, cluster 1 with 8 farms showed the highest CF (1.09) as explained by a low milk production, low milk yield, and a low efficiency in herd composition. This group was dominated by farms that did not feed sufficient concentrate per cow $(2.6 \mathrm{~kg} / \mathrm{cow} /$ day $)$ along with reduced forage intake $(8.3 \mathrm{~kg}$ $\mathrm{DM} /$ cow/day). Feed intake (total forage plus concentrate) was lower than the average $(11.0 \mathrm{vs} .13 .3 \mathrm{~kg}$ $\mathrm{DM} /$ cow/day averaged over all farms) probably due to poor forage production where the amount of purchased concentrate did not compensate for the reduced forage available per cow. As a consequence of poor animal performance (milk yield per cow and herd efficiency), the enteric $\mathrm{CH}_{4}$ contribution to GHG emission was greater than the other two clusters. This cluster is most similar to the average Uruguayan dairy system.

Cluster 2 showed an intermediate CF (0.96) associated with an intermediate milk production and milk yield per cow. A characteristic of this cluster of farms was the highest consumption of concentrate per cow $(6.3 \mathrm{~kg}$ $\mathrm{DM} /$ cow/day) with a relatively low consumption of pasture $(7.0 \mathrm{~kg} \mathrm{DM} / \mathrm{cow} /$ day $)$ and a total feed intake of 13.3 $\mathrm{kg} \mathrm{DM} /$ cow/day. As a result, DM intake of concentrates was not efficiently converted to milk: $0.39 \mathrm{~kg} \mathrm{DM}$ concentrate/kg FPCM compared to 0.32 averaged over the 24 dairy farms. This indicates that forage availability per cow was limited (only $53 \%$ of the total DM intake per cow).

Cluster 3 corresponded to the 9 farms with the lowest CF. Average milk yield per cow and feeding parameters reflect an intensification of milk production on these farms. Farms from cluster 3 also supplied a high amount of concentrate feed $(5.9 \mathrm{~kg} \mathrm{DM} / \mathrm{cow} /$ day $)$ with forage consumption greater than that in cluster $2(9.3 \mathrm{~kg}$ $\mathrm{DM} / \mathrm{cow} /$ day). So, total feed consumption was $15.2 \mathrm{~kg} \mathrm{DM} / \mathrm{cow} /$ day on average, with the most efficient conversion of DM to milk. Additionally, these farms had the highest herd efficiency, which means less replacement animals required per cow. 
The multivariate analysis conducted in this study showed that emission could be reduced by at least $15 \%$ if farmers from cluster 1, representative of most of the dairy farmers in Uruguay, adopted management practices which are currently applied by farmers of cluster 3 . Addittionaly, this mitigation option will result in an increase in milk production. Gerber et al. (2013) also identified that management differences between milk produced with the lowest $\mathrm{CF}$ and that with the highest provides the greatest opportunity for mitigation.

Previous reports have concluded that improvement in animal production will increase methane emission per animal but ultimately reduce methane production per unit of milk produced (Mc Geough et al., 2012; Rotz et al., 2010; Lovett et al., 2006). The focus to reduce CF has led to increasing the feeding of concentrates as a tool to increase milk production. However in grazing systems, efficiency of production depends highly on the use of pastures. Therefore, it is relevant to understand the combined effect of pasture and concentrate utilization in the performance of the integral system. For instance, Casey and Holden (2005b) reported that high concentrate feeding on Irish grazing systems often implies inefficient feed management. Their results showed that over feeding concentrates in grazing systems not only erodes profit but also leads to a greater CF. An increase in concentrate supply without efficient use of pastures will tend to increase CF.

Inadequate nutrition is one of the main factors limiting ruminant production (Gerber et al., 2013). Low forage intake is often a consequence of over-grazing practices associated with a high stocking rate on low yielding pastures. As a result, some farmers try to compensate lower forage intake by increasing the amount of concentrate fed per cow, but this leads to a low efficiency in milk production per unit of total dry matter intake. Inefficient feed management practice was also highlited as an important feature for improving CF on dairy grazing systems in Ireland (Yan et al., 2013; Casey \& Holden, 2005b). Research, development and education are needed to avoid dairying practices with limited forage availability and inefficient feeding managements. The adoption of efficient technologies and good management practices to overcome these problems will lead to an increase in milk yield, reducing the CF of milk produced in grazing dairy systems while likely improving farm profitability.

\section{Conclusions}

In this first assessment of milk CF for Uruguayan dairy production systems, average milk CF for the 24 farms studied was $0.99 \mathrm{~kg} \mathrm{CO} 2 \mathrm{eq} / \mathrm{kg}$ FPCM with a variation of $\pm 10 \%$. Farms with more efficient production in terms of greater milk yield and a greater ratio of milking cows to total stock (i.e. early age at first calving and lower replacement rate) provided a lower milk CF. Lower CF was also associated with higher feed dry matter intake per cow using an appropriate mixture of pasture and concentrate feeds.

In grazing systems, efficiency of production depends highly on the use of pasture forage. An increase in concentrate supply without efficient use of pasture did not provide an expected reduction in CF. Low forage intake per cow in Uruguay is often a consequence of high stocking rates on low yielding pastures. Technical advice on feeding is needed to increase forage intake (grazed or conserved forage) and as a consequence to use concentrate feeds more efficiently. Improved grazing management will increase milk yield, reducing the CF of the milk produced while likely improving farm profitability.

The CF has become a relavant issue for Uruguay due to the high export of commodities and growing international consumer concern over a product's CF. From an exporting nation's perspective, Uruguay should adopt measures to provide environmentally as well as economically competitive products. Policies like labelling and certificate programmes, along with economic incentives, are needed to encourage farmers to mitigate emissions.

\section{Acknowledgements}

The authors express their gratitude to FUCREA (Federación Uruguaya de Consorcios Regionales de Experimentación Agrícola, Uruguay) technical advisors and the farmers participating in the study. As well as to Dr. Walter Beathgen (International Research Institute for Climate and Society, Columbia University, New York, United States) and Dr. Alejandro La Manna (Instituto Nacional de Investigación Agropecuaria, Colonia, Uruguay) for their suggestions on the study. This research was funded partially by grants from the United Nations Program for Development (PNUD).

\section{References}

AFRC (Agricultural and Feed Research Council). (1993). Energy and protein requirements of ruminants. Wallingford, UK: CAB International.

ALADI (Asociación Latinoamericana de Integración). Sistema de Información de Comercio Exterior. (2011). Estadisticas por item arancelario de un pais. Retrieved July 28, 2011, from 
http://consultaweb.aladi.org/sicoex/jsf/comercio_exterior_item_arancelario.seam?cid=2739

Astigarraga, L. (Coordinadora técnica). (2004). Modelo de decisión lechero: análisis de alternativas productivas. In "Intensificación en lechería: la alternativa rentable". (pp. 24-32). Montevideo, Uruguay: INIA-FUCREA-FAGRO. $\quad$ FPTA $101 . \quad$ Retrieved from http://www.fucrea.org/informacion/index.php?TypeId=15\&ClassId=49\&Id=1195

Basset-Mens, C., Ledgard, S., \& Boyes, M. (2009). Eco-efficiency of intensification scenarios for milk production in New Zealand. Ecological Economics, 68(6), 1615-1625. http://dx.doi.org/10.1016/j.ecolecon.2007.11.017

Belflower, J. B., Bernard, J. K., Gattie, D. K., Hancock, D. W., Risse, L., \& Rotz, C. A. (2012). A case study of the potencial environmental impacts of different dairy production systems in Georgia. Agricultural Systems, 108, 84-93. http://dx.doi.org/10.1016/j.agsy.2012.01.005

Beukes, P. C., Gregorini, P., Romera, A. J., Levy, G., \& Waghorn, G. C. (2010). Improving production efficiency as a strategy to mitigate greenhouse gas emissions on pastoral dairy farms in New Zealand. Agriculture, Ecosystems \& Environment, 136(3/4), 358-365. http://dx.doi.org/10.1016/j.agee.2009.08.008

Cabal, C., Fontana, F., García Pini, E., \& Kramer, R. (2009). Cálculo del factor de emisiones del $\mathrm{CO}_{2}$ del sistema eléctrico uruguayo 2008: Estimación para el PDD. Retrieved from http://www.ute.com.uy/pags/Institucional/documentos/Calculo\%20del $\% 20$ factor $\% 20 \mathrm{de} \% 20 \mathrm{emisiones} \% 20 \mathrm{~d}$ e\%20CO2_\%202008.pdf

Casey, J. W., \& Holden, N. M. (2005a). Analysis of greenhouse gas emissions from the average Irish milk production system. Agricultural Systems, 86(1), 97-114. http://dx.doi.org/10.1016/j.agsy.2004.09.006

Casey, J. W., \& Holden, N. M. (2005b). The relationship between greenhouse gas emissions and the intensity of milk production in Ireland. Journal of Environmental Quality, 34(2), 429-436. http://dx.doi.org/10.2134/jeq2005.0429

Castanheira, E. G., Dias, A. C., Arroja, L., \& Amaro, R. (2010). The environmental performance of milk production on a typical Portuguese dairy farm. Agricultural Systems, 103(7), 498-507. http://dx.doi.org/10.1016/j.agsy.2010.05.004

Cederberg, C., \& Stading, M. (2003). System expansion and allocation in life cycle assessment of milk and beef production. The International Journal of Life Cycle Assessment, 8(6), 350-356. http://dx.doi.org/10.1007/BF02978508

Crosson, P., Shalloo, L., O’ Brien, D., Lanigan, G. J., Foley, P. A., Boland, T. M., \& Kenny, D. A. (2011). A review of whole farm systems models of greenhouse gas emissions from beef and dairy cattle production systems. Animal Feed Science and Technology, 166-167, 29-45. http://dx.doi.org/10.1016/j.anifeedsci.2011.04.001

CUSA (Cámara Uruguaya de Servicios Agropecuarios). (2011). Precios sugeridos de labores agrícolas. Retrieved July 28, 2011, from http://www.cusa.org.uy/precios_servicios_agricolas.html

Díaz- Rosello, R., \& Durán, H. (2011). Secuestro de carbono en suelos de sistemas agrícola-lecheros mixtos en Uruguay. Agrociencia Uruguay, 15(2), 109-119.

DIEA (Estadísticas Agropecuarias). (2009). La producción lechera en el Uruguay año 2007 Serie Trabajos Especiales

Retrieved

from http://www.mgap.gub.uy/portal/agxppdwn.aspx?7,5,108,O,S,0,401\%3BS\%3B9\%3B120

DIEA (Estadísticas Agropecuarias). (2010). Estadísticas del sector lácteo. Serie Trabajos Especiales, (295). Retrieved from http://www.mgap.gub.uy/portal/agxppdwn.aspx?7,5,104,O,S,0,2127\%3bS\%3b4\%3b120,

DIEA (Estadísticas Agropecuarias). (2012). Anuario estadístico agropecuario 2011. Retrieved from http://www.mgap.gub.uy/portal/hgxpp001.aspx?7,5,583,O,S,0,

DIEA (Estadísticas Agropecuarias). (2013). Anuario estadístico agropecuario 2012. Retrieved from http://www.mgap.gub.uy/portal/hgxpp001.aspx?7,5,754,O,S,0,MNU;E;27;9;MNU;,

DINAMA (Dirección Nacional de Medio Ambiente). Unidad de Cambio Climático. (2010). Inventario nacional de emisiones de gases de efecto invernadero 2004: Evolución de emisiones de gases de efecto invernadero 1990-2004.

Retrieved

from http://www.cambioclimatico.gub.uy/images/stories/documentos/marco_legal/publicaciones/ingei_2004_re.p df 
Dini, Y., Gere, J., Briano, C., Manetti, M., Juliarena, P., Picasso, V., ... Astigarraga, L. (2012). Methane emission and milk production of dairy cows grazing pastures rich in legumes or rich in grasses in Uruguay. Animals, 2(2), 288-300. http://dx.doi.org/10.3390/ani2020288

Flysjö, A., Henriksson, M., Cederberg, C., Ledgard, S., \& Englund, J. (2011). The impact of various parameters on ther carbon footprint of milk production in New Zealand and Sweden. Agricultural Systems, 104(6), 459-469. http://dx.doi.org/10.1016/j.agsy.2011.03.003

Gerber, P. J., Steinfeld, H., Henderson, B., Mottet, A., Opio, C., Dijkman, J., ... Tempio, G. (2013). Tackling climate change through livestock: A global assessment of emissions and mitigation opportunities. Rome, Italy, FAO. Retrieved from www.fao.org/docrep/018/i3437e/i3437e.pdf

Guerci, M., Bava, L., Zucali, M., Sandrucci, A., \& Penati, C. (2013). Effect of farming strategies on environmental impact of intensive dairy farms in Italy. Journal of Dairy Research, 80(3), 300-308. http://dx.doi.org/10.1017/S0022029913000277

Hagemann, M., Hemme, T., Ndambi, A., Alqaisi, O., \& Sultana, N. (2011). Benchmarking of greenhouse gas emissions of bovine milk production systems for 38 countries. Animal Feed Science and Technology, 166-167, 46-58. http://dx.doi.org/10.1016/j.anifeedsci.2011.04.002

Henriksson, M., Flysjö, M., Cederberg, C., \& Swensson, C. (2011). Variation in carbon footprint of milk due to management differences between Swedish dairy farms. Animal, 5(9), 1474-1484. http://dx.doi.org/10.1017/s1751731111000437

Hermansen, J. E., \& Kristensen, T. (2011). Management options to reduce the carbon footprint of livestock products. Animal Frontiers, 1(1), 33-39. http://dx.doi.org/10.2527/af.2011-0008

Hospido, A., Moreira, M. T., \& Feijoo, G. (2003). Simplified life cycle assessment of Galician milk production. International Dairy Journal, 13(10), 783-796. http://dx.doi.org/10.1016/S0958-6946(03)00100-6

IDF (International Dairy Federation). (2010). A common carbon footprint approach for dairy: The IDF guide to standard lifecycle assessment methodology for the dairy sector. Bulletin of the International Dairy Federation, 445, 1-40. http://www.fil-idf.org/Public/Download.php?media=38058

InfoStat. (2012). Software estadistico. Córdoba, Argentina: UNC. Retrieved from http://www.infostat.com.ar/

Iribarren, D., Hospido, A., Moreira, M. T., \& Feijoo, G. ( 2011). Benchmarking environmental and operational parameters through eco-efficiency criteria for dairy farms. Science of The Total Environment, 409(10), 1786-1798. http://dx.doi.org/10.1016/j.scitotenv.2011.02.013

IPCC (Intergovernmental Panel on Climate Change). (2006a). Guidelines for National Greenhouse Gas Inventories: Agriculture, forestry and other land use. In H. Dong, J. Mangino, T. A. McAllister, J. L. Hatfield, D. E. Johnson, ... A. Romanovskaya (Working group). Emissions from livestock and manure management. Hayama, Kanawaga, Japan: IGES. Retrieved from http://www.ipcc-nggip.iges.or.jp/public/2006gl/pdf/4_Volume4/V4_10_Ch10_Livestock.pdf

IPCC (Intergovernmental Panel on Climate Change). (2006b). Guidelines for National Greenhouse Gas Inventories: Agriculture, forestry and other land use. In C. De Klein, R. S. A. Novoa, S. Ogle, K. A. Smith, P. Rochette, T. C. Wirth , ... K. Rypdal (Working group). $\mathrm{N}_{2} \mathrm{O}$ emissions from managed soils, and $\mathrm{CO}_{2}$ emissions from lime and urea application. Hayama, Kanawaga, Japan: IGES. Retrieved from http://www.ipcc-nggip.iges.or.jp/public/2006gl/pdf/4_Volume4/V4_11_Ch11_N2O\&CO2.pdf

IPCC (Intergovernmental Panel on Climate Change). (2006c). Guidelines for National Greenhouse Gas Inventories: Energy. Garg, A., Kazunari, K., \& Pulles, T. (Working group). Introduction. Hayama, Kanawaga, Japan: IGES. Retrieved http://www.ipcc-nggip.iges.or.jp/public/2006gl/pdf/2_Volume2/V2_1_Ch1_Introduction.pdf

IPCC (Intergovernmental Panel on Climate Change). (2007). Climate change 2007: the physical science basis; Contribution of Working Group I to the Fourth Assessment Report of the Intergovernmental Panel on Climate Change. In S. D. Solomon, M. Qin, Z. Manning, M. Chen, K. B. Marquis, M. Averyt, ... H. L. Miller (Eds.). Cambridge, UK: CUP. Retrieved from http://www.ipcc.ch/publications_and_data/publications_ipcc_fourth_assessment_report_wg1_report_the_ph ysical_science_basis.htm

Kristensen, T., Mogensen, L., Knudsen, M. T., \& Hermansen, J. E. (2011). Effect of production system and farming strategy on greenhouse gas emissions from commercial dairy farms in a life cycle approach. 
Livestock Science, 140(1/3), 136-148. http://dx.doi.org/10.1016/j.livsci.2011.03.002

Lovett, D. K., Shalloo, L., Dillon, P., \& O'Mara, F. P. (2006). A system approach to quantify greenhouse gas fluxes from pastoral dairy production as affected by management regime. Agricultural Systems, $88(2 / 3)$, 156-179. http://dx.doi.org/10.1016/j.agsy.2005.03.006

Lovett, D. K., Shalloo, L., Dillon, P., \& O'Mara, F. P. (2008). Greenhouse gas emissions from pastoral based dairying management change under two contrasting production systems. Livestock Science, 116(1/3), 260-274. http://dx.doi.org/10.1016/j.livsci.2007.10.016

Massart, D. L., Vandeginste, B. G. M., Deming, S. N., Michotte, Y., \& Kaufman. L. (1988). Principal components and factor analysis. (pp. 339-370). In Chemometrics: A textbook. Amsterdam, The Netherlands, Elsevier. http://dx.doi.org.proxy.timbo.org.uy:443/10.1016/S0922-3487(08)70234-X

Mc Geough, E. J., Little, S. M., Janzen, H. H., McAllister, T. A., McGinn, S. M., \& Beauchemin, K. A. (2012). Life- cycle assessment of greenhouse gas emissions from dairy production in Eastern Canada: A case study. Journal of Dairy Science, 95(9), 5164-5175. http://dx.doi.org/10.3168/jds.2011-5229

O'Brien, D., Shalloo, L., Patton, J., Buckley, F., Grainger, C., \& Wallace, M. (2012). A life cycle assessment of seasonal grass-based and confinement dairy farms. Agricultural Systems, 107, 33-46. http://dx.doi.org/10.1016/j.agsy.2011.11.004

Rotz, C. A., Montes, F., \& Chianese, D. S. (2010). The carbon footprint of dairy production systems through partial life cycle assessment. Journal of Dairy Science, 93(3), 1266-1282. http://dx.doi.org/10.3168/jds.2009-2162

Rotz, C. A., Soder, K. J., Skinner, R. H., Dell, C. J., Kleinman, P. J., Schmidt, J. P., \& Bryant, R. B. (2009). Grazing can reduce the environmental impact of dairy production systems. Forage and Grazinglands, http://dx.doi.org/10.1094/FG-2009-0916-01-RS

Spielmann, M., Dones, R., \& Bauer, C. (2007). Life cycle inventories of transport services: Final report ecoinvent data v2.0. 14. Dübendorf, Swiss Centre for LCI. Verified January 17, 2014, from http://www.ecoinvent.org/support/old-doc/rep/reports-for-guests-users/

Yan, M. J., Humphreys, J., \& Holden, N. M. (2013). Life cycle assessment of milk production from commercial dairy farms: The influence of management tactics. Journal of Dairy Science, 96(7), 4112-4124. http://dx.doi.org/10.3168/jds.2012-6139

\section{Copyrights}

Copyright for this article is retained by the author(s), with first publication rights granted to the journal.

This is an open-access article distributed under the terms and conditions of the Creative Commons Attribution license (http://creativecommons.org/licenses/by/3.0/). 